\title{
SEMANTIC FUNCTION OF THE INANIMATE-SUBJECT IN PERSIAN
}

-Toward a Syntactic Study of Persian Verbs on Semantic Principles-

Shôzô YOKOYAMA*

\begin{abstract}
This $^{(1)}$ is the first of a series of papers that, taken together, will give an approach to modern Persian grammar on semantic principles. In this paper I attempt to examine semantic function of the inanimate-subject in the 'Subject+Object+Verb' transitive verb constructions, based on the framework of Fillmore's 'Case Grammar' theory ${ }^{(2)}$.

The argument, here, will explore the case priority in the inanimate-subject position and the possibility of a hidden agentive subject in some inanimatesubject in transitive verb constructions. In addition, this paper suggests that the variety of subjects in Persian shall be attributed to the restricted word order: Subject + Object + Verb. This restriction plays an important role in granting the subject various semantic roles.
\end{abstract}

\section{Introduction}

The main purpose of this paper, first of all, is to provide a framework of a subject-oriented (or noun phrase oriented) data analysis rather than verboriented one, specified to the inanimate-subject sentences in Persian which shall reinforce the validity of case theory. And hopefully, the possibility of adaptation of this research to the lexicology shall be emphasized. Before we turn to the close examination of the case theory, it will be useful to refer to the fundamental function of a sentence from different view points.

Any sentence features in a given language shall be analyzed from the various kinds of aspects. Ancient Greek grammarians classified sentence elements in terms of parts of speech; nouns, verbs, adjectives etc. We can also

* Associate Professor, Civil Aviation College, Ministry of Transport

Vol. XXXIII 1998 
categorize them according to its semantic features; humans, animals, things, etc.

Basically, each element which constitutes a sentence shall be analyzed functionally so as to show their organic relation they have with each other. Those are: grammatical function ${ }^{(3)}$, discourse function $^{(4)}$ and semantic function ${ }^{(5)}$. And we could say that the analysis by case grammar is one of the ways of sentence analysis from a viewpoint of semantic function.

\section{Verb patterns in case grammar}

Various arrangements of cases within a sentence determine the verb patterns, and it also enables us to establish semantic categories of Persian verbs. The verb patterns here shall represent an indication of patterns in terms of semantic function, not the grammatical function, thus its indication can be decided and realized regardless of its word order or the distinction between transitive and intransitive verbs. The environment of cases which a verb may cause is called 'case frame'. The case features in the examples of garm kardan 'to warm', treated in Notes (5), shall be illustrated as V[Ag+Af+I] in (a), $\mathrm{V}[\mathrm{I}+\mathrm{Af}]$ in (b) and V[Af] in (c) (V = Verb), hence the 'frame features' shall be identified as $\mathrm{V}[\mathrm{Af}+(\mathrm{Ag})+(\mathrm{I})]$. In this frame feature, the Affected case is an obligatory feature, whereas the other cases with bracket are optional.

We will then move on to the discussion on the case relation in the inanimate-subject sentence in the next chapter.

\section{Semantic relation of case features in inanimate-subject sentence}

It seems that the 'inanimate-subject' has not neccesarily been a major topic in Persian linguistics, although it provides us with an interesting contact of syntax and semantics.

We shall start looking at some of the typical examples of the inanimate subject: natural phenomena.
(1) barf va sarmâ râhhâ-râ liz karde 'ast. snow and cold roads-obj. slippery made have(auxiliary) 'Snow and cold have made the roads slippery.'
(2) vazeš-e bâd barghâ-râ bord. a puff of wind leaves-obj. brought


'A puff of wind blew the leaves away.'

(3) bârân faršhâ-râ tar karde 'ast. rain rugs-obj. wet made have(auxiliary)

'The rain has made the rugs wet.'

(4) nur-e 'âftâb mivehâ-râ mirasânad. sunshine fruits-obj. ripens

'Sunshine ripens the fruits.'

When we observe the subject in (1), the immediate cause which 'have made the roads slippery' is 'snow and cold', and in (2), the force which 'blew the leaves away' is thus 'a puff of wind'. Likewise the 'rain' in (3), and the 'sunshine' in (4) are all recognized as the 'instrumental case' which produced a change of event on the object denoted by the verb.

Considering the object in the sentences, on the other hand, we can easily understand that the 'roads' in (1) is recognized as the object which has been made slippery, and in the same way, the 'leaves' in (2) as the one which have been blown away. Thus, all of the object should be regarded as the 'affected case'.

Let us now propose a hypothetical formalization about the semantic relations of inanimate-subject sentences with a transitive verb as follows;

F1. In an inanimate-subject sentence with a transitive verb, when the subject is an instrumental case, then the object will be an affected case.

The instrument case was originally defined as the case which denotes the 'things used' by an agent which causes a certain action. To put it another way, there definitely exists a hidden agent when the instrument case appears in a sentence. The following examples in (5) and (6) seem to support the theory.

(5) 'âteš dasthâyeš-râ garm kard.

fire his hands-obj. warmed up

'Fire warmed up his hands.'

(6) hasan dasthâyě̌-râ bâ 'âtě̌ garmkard.

Hasan his hands-obj. with fire warmed up

'Hasan warmed up his hands with fire.' 
Note that, in (5), the grammatical [subject - object] relation is mapped onto the [instrumental - affected] case relation. This is a typical demonstration of the above hypothesis F1. On the other hand, in (6), the sentence has the [agentive affected - instrumental] case relation, in which the subject position is occupied by the agentive case. Given that the sentence (6) is a deep structure sentence, it is reasonable to suppose that the sentence (5) have been derived from it with its instrumental 'âteš having been moved to the subject position and the original subject hasan being hidden in a surface structure. Furthermore, (7) represents the minimum-element sentence in which the instrumental has disappeared and only the affected remains.

\section{(7) dasthâyeš garm ̌̌od. his hands warmed up \\ 'His hands warmed up.'}

These case relations, including the intransitive-verb sentence, can be illustrated as in Figure 1.

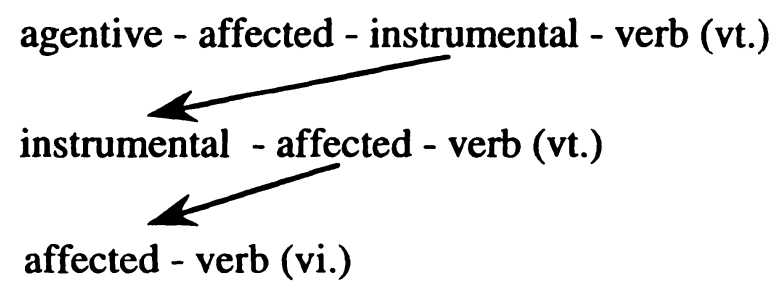

Figure 1. Case priority in subject position

As far as the three cases - agentive, instrumental and affected - are concerned, we see from Figure 1 that the subject position will normally be occupied by the agentive case, and if there is not an agentive in a sentence, the instrument will take place the subject position, and finally the affected will become a subject if both the agent and instrument do not appear in a sentence. Accordingly the formalization F1 should be modified as F2;

F2. Case priority in subject position : agentive $>$ instrumental $>$ affected (high priority $>$ low priority) 
All the instrumental-subject sentences, however, do not have the agentives as (7) in their deep structures, hence they never appear in (1), (2), (3) and (4). Those cases which do not have a hidden agentive could be designated as 'force' and differentiated from instrumental cases. This is one of the reasons Fillmore redefined the instrument as an 'immediate cause' from aforementioned 'things used'(6). $^{\prime}$.

In any case, the validity of $F 2$, regardless of the existence of a hidden agent, shall be guaranteed further by the fact that the affected cases in (1), (2), (3) and (4) can all take the place of the subject position as in (8), (9), (10) and (11).
$\begin{array}{llll}\text { (8) } & \text { râhhâ } & \text { liz } & \text { sode 'ast. } \\ \text { roads } & \text { slippery become have }\end{array}$
'The roads have become slippery.'
(9) barghâ borde šod.
leaves swept away were
'The leaves were swept away.'
(10) faršhâ tar šode 'ast.
carpets wet become have
'The carpets have become wet.'
(11) mivehâ mirasad.
fruits ripens
'The fruits ripens.'

There are, as is seen in (7), other examples of inanimate-subject sentence with hidden agent which is recognizable from the context as follows.

(12) 'in naqqấsihâ tarz-e zendegi-ye mardomân-e qârnešin this pictures style-of life-of people-of cave dweller něsân midehad.

show

'This picture illustrates the life style of cave dwellers.'

(13) sedâhâ-ye boland marizân-râ nârâhat mikonad.

noise-of loud patients-obj. disturb

'Loud noise disturb the patients.' 
Naturally these hidden agents do not appear as noun phrases on the surface of the sentences, thus shall be guessed by their context. Notice that, unlike the above examples, the agent can be incorporated in the inanimate subject combined by 'ezâfe.

$$
\text { tarz-e notq-e 'u tavajjoh-e hozzâr-râ jalb namud. }
$$
style-of speech-of he attention-of attendance-obj. attracted 'His style of speech attracted everybody's attention.'

nasihat-e mohammad zaxmhâ-ye ruhi-ye ma-râ 'eltiyâm dâd. advice-of Mohammad wound-of spirit-of me-obj. healed 'The advice of Mohammad healed my spiritual wound.'

We have so far discussed the relationship between the instrumental subject and the affected object sentences. And further investigation on the nature of case relations leads us to the fact that the instrument case, for example, appears in the subject position and locative case in the object position as in (16), even the locative case sometimes appear in the subject position, although a rare occurence.

$$
\begin{array}{lllll}
\text { bu-ye } & \text { gol-esorx } & \text { 'otâq-râ } & \text { porkarde } & \text { 'ast. } \\
\text { smell-of } & \text { roses } & \text { room-obj. } & \text { filled } & \text { has }
\end{array}
$$

'The smell of roses has filled the room.'

$$
\begin{array}{llll}
\text { 'in 'otomobil } & \text { šes nafar jâ migirad. } \\
\text { this car } & \text { six people holds }
\end{array}
$$

'This car holds six people.'

The case features which appear in a sentence is automatically predetermined by the semantic features each verb possesses, and in that sense, the verbs jâ gereftan which permit the locative subject as seen in (17) are quite limited. Another example of locative subject occurs in the sentence with dâštan 'to have, to possess' as in $(18)^{(7)}$ which normally denotes possession.

$$
\begin{aligned}
& \text { 'in 'emârat manzare-ye xubi dârad. } \\
& \text { this building view-of good has } \\
& \text { 'This building commands a good view.' }
\end{aligned}
$$


It should be noted here that constructions with dâštan can primarily be split into two major expression categories from a semantic point of view.

(19) man ketâbi dâram.

I a book have

'I have a book.'

(20) doxtar-e man yek gorbe dârad. daughter-of I a cat has

'My daughter has a cat.'

(21) žâpon kuhhâ-ye boland ziyâd dârad. Japan mountains-of high many has 'Japan has many high mountains.'

(22) 'in bâq deraxtân-e sib ziyâd dârad. this garden trees-of apple many has 'This garden has many apple trees.'

(23) 'in 'otâq šeš panjare dârad. this room six window has

'This room has six windows.'

It is obvious that in (19) and (20) the verb dâshtan denotes the possession of ketâb 'book' and gorbe 'cat' by an animate subject respectively, while (21) through (23), having the locative subjects, are all recognized as 'locative' construction. The difference of those two features shall be characterized by the fact that the 'locative' construction can be paraphrased with the verb budan 'to be' as in (24), although the 'possession' construction cannot ${ }^{(8)}$.

$$
\begin{aligned}
& \text { dar 'in 'otâq šeš panjare 'ast. }{ }^{(9)} \\
& \text { in this room six windows are } \\
& \text { 'There are six windows in this rooms.' }
\end{aligned}
$$

Additionally, (23) can be paraphrased for locative subject construction of an intransitive verb as in (25), accompanying an obligatory prepositional phrase followed by 'az 'from'.

$$
\begin{array}{clllll}
\text { 'in 'otâq 'az } & \text { bu-ye } & \text { gol-e sorx por šode 'ast. } \\
\text { this room with smell-of roses } & \text { filled become has }
\end{array}
$$


'This room has been filled with the smell of roses.'

Again, let us shed a light on the 'hidden agent' that has already been referred to in the previous argument. Here we can see that the hidden agent in the locative subject constructions also have both patterns as is the case with instrumental subject constructions. That is; neither (17) nor (18) could imply the existence of a hidden agent, but (16) possibly could as is shown in (26).

(26) širin 'otâq-râ 'az bu-yegol-esorx porkarde 'ast. Shirin room-obj. with smell-of roses filled has 'Shirin has filled the room with the smell of roses.'

We must now return to the formalization which I have proposed in the previous chapter;

F2. Case priority in subject position : agentive $>$ instrumental $>$ affected (high priority $>$ low priority)

The case relations in (25) and (26) are observed as follows;

(25) locative - instrumental - verb (Vi)

(26) agentive - locative - instrumental - verb ( $\mathrm{Vt})$

The following constructions, (27) and (28), which are transformed from (25), with its locative and instrument case having been placed in the subject position, are both unacceptable.

(27) ? 'in 'otâq por šode 'ast. *'This room has been filled.'

(28) ? bu-ye gol-e sorx por šod. *'The smell of roses has filled.'

This indicates that the two cases - locative and instrumental - appear or exist in a construction mutually obligatory, hence the following case relation with regard to the instrumental subject will be proposed in addition to the formalization to F2 stated above; 
F3. Case priority for subject position (instrumental subject): agentive $>$ locative - instrumental

Furthermore, we have another case possibility of inanimate subject: the recipient case, although the implication of hidden agents can also hardly be recognized in these recipient subject constructions.

$$
\begin{aligned}
& \text { (29) 'in mâšin ta'mir lâzem dârad. } \\
& \text { this car a fix needs } \\
& \text { 'This car needs a fix.' } \\
& \text { 'in kâr moškelât-e ziyâdi darbardârad. } \\
& \text { this task difficulties-of many involves }
\end{aligned}
$$
'This task involves many difficulties.'

dowlat-e 'irân cin-râ be rasmiyat šenâxt.
government-of Iran China-obj. officially recognized 'Iran's government officially recognized China.' dâdgâh 'ezhârât-e šâhed-râ 'estemâ' kard. court statements-of witness-obj. heard 'The court heard the witness's statements.' majles lâyehe-ye jadid-râ tasvibkard. parliament bill-of new-obj. approved 'The parliament approved the new bill.' 'in kešvar 'amniyat-e xalij-e fârs-râ tazmin mikonad. this country security-of Persian Gulf-obj. guarantees 'This country guarantees the security of the Persian Gulf.'

The facts resulting from the above argument clearly shows that there is a certain hierarchy among the inanimate-subject constructions; some of which can be granted to be 'true' inanimate and others can be implied to have a hidden agent.

\section{Conclusion}

In this paper, I have clarified the following points;

1. Inanimate-subject in Persian transitive verb constructions may assume three different semantic roles: 
(a) instrumental case subject (instrument, immediate cause, etc.)

(b) locative case subject (location, position)

(c) recipient case subject

2. Inanimate-subject construction with Persian transitive verbs may have a hidden agent in its base structure; otherwise it is 'true' inanimate as natural phenomena such as 'rain', 'snow' or 'wind'.

3. Given an agentive, instrumental and affected case in a certain construction, the case priority for the subject position shall be firstly given to the agent, next to the instrumental, and finally to the affected case. And since the two cases of locative and instrumental case appear in a construction mutually obligatory, there is an equal priority between the locative and instrumental case.

4. As we have observed, various inanimate-subject constructions are permitted in Persian. This can be attributed to the fact that such a fixed word order in Persian as ' $\mathrm{S}+\mathrm{O}+\mathrm{V}$ ' inevitably causes a restricted expression frame, which, as a result grants a subject various semantic roles.

Finally I would like to emphasize some possible adaptations of the theory which we have examined in this paper to the field of lexicology in Persian.

In the world of meaning, an objective description is believed to be difficult and sometimes barely possible, even if it does not go so far as to be subjective. The case grammar, however, provides us with an efficient mean for lexical description, in spite of attracting some criticism ${ }^{(10)}$. Firstly, it is indispensable for the study of basic vocabulary of a given language, since it helps to clarify lexical rules and selectional restrictions of its collocations each lexis possesses; Secondly, the results of its analysis should be made the best use of for the description of lexical words in the dictionary.

As is shown in the early chapter, the case grammar gives us a different view point which we would never have been aware of using the traditional sentence-pattern indication. Traditional lexical description, although no Persian dictionaries have ever tried to indicate sentence patterns so far, has simply defined the word as 'to open (something)' in general. We should now be able to give it a far more careful and minute description when combined with the grammatical sentence-pattern indication, and further research should progress toward the reclassification of verbs by semantic features, such as verbs with a same 'frame features' as bâz kardan, xam kardan 'to bend' and gardândan 'to 
rotate'.

The future direction of this study will be to deepen the argument on the semantic relationships between verbs and other elements in a broad sense, and hopefully to divide the verbs according to the semantic types and describe how the semantic roles are mapped onto syntactic relations in effect ${ }^{(11)}$.

\section{Notes}

* I am grateful to Prof. Tetsuo Nawata at Tokyo University of Foreign Studies and Prof. Koji Kamioka at the Institute for the Study of Languages and Cultures of Asia and Africa, Tokyo University of Foreign Studies for valuable comments and suggestions, and my special thanks are also due to Mr. Ali Parvin in London who gave me useful comments for the listed data.

(1) The present paper is the revised version of my article in Japanese (横山彰三「ペル シャ語無生物主語構文における主語の担う意味的機能」「航空大学校研究報告 R-51」(1997 年)). The earlier version was originally read at the 35th annual meeting of the Society for Near Eastern Studies in Japan (NIPPON ORIENTO GAKKAI) held at Seitoku University in 1993.

(2) Background of case grammar theory; Charles Fillmore casts a doubt on the validity of the deep structure and branched off from Chomsky's Standard Theory, developing his own language theory. He claims that the notional concept, 'a subject' or 'an object', does not directly contribute to the semantic interpretation, and proposed a deeper level of semantic interpretation. His contribution laid the foundation for the development of a semantic function oriented 'case grammar'. According to Blake (1994), theories posting a universal set of semantic relations include Fillmore's proposal for Case Grammar, John Anderson's Localist Case Grammar, Starosta's Lexicase and Dik's Functional Grammar.

( 3 ) Sentence patterns, or verb patterns, are the results of sentence analysis from the point of grammatical function, each element being classified as a subject, a verb, an object and a complement. I have classified and exemplified those Persian verb patterns into 7 groups, including adjective patterns as follows.

(i) $[\mathrm{S}+\mathrm{V}]$ pattern

'u mord.

he died

'He died.'

(ii) $[\mathrm{S}+\mathrm{C}+\mathrm{V}]$ pattern

pari dânešju 'ast.

Pari student is

'Pari is a student.'

(iii) $[\mathrm{S}+\mathrm{A}+\mathrm{V}]$ pattern

'u 'az sandari 'oftâd.

he from chair fell

'He fell off the chair.'

(iv) $[\mathrm{S}+\mathrm{O}+\mathrm{A}+\mathrm{V}]$ pattern

mahmud livân-râ šekast.

Mahmud cup-obj. broke

'Mahmud broke the cup.'

(v) $[\mathrm{S}+\mathrm{O}+\mathrm{C}+\mathrm{V}]$ pattern 


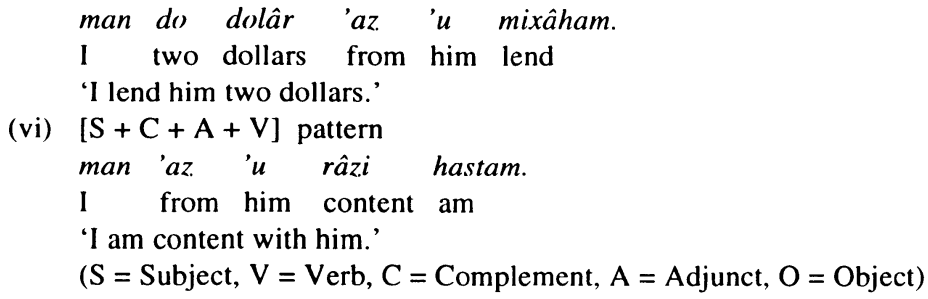

For a discussion of the analysis by grammatical function in Persian, see Yokoyama (1992) and Yokoyama (1994).

(4) This function is concerned with the syntactic relation beyond a simple sentence. In other words, discourse function deals with intra-sentential correspondence or reference of syntactic features. Here are a few examples of that:
(a) ketâb 'injâ 'ast.
the book here is
'The book is here.'
(b) 'injâ ketâbi hast.
here a book is
'There is a book here.'

As far as the grammatical function is concerned, the difference between these two sentences can only be described as the positional difference of the noun phrase ketâb in the sentences. Our major concern here is, however, to explain what semantic difference it can cause in such word order. The best way to understand its difference semantically is to compare them in the framework of old and new information. In other words, we can attribute the difference between (a) and (b) to the difference of presupposition for each sentences. When we utter a question ketâb kojâst? which means 'Where is the book?', the respond to it should be (a), not (b). The ketâb 'the book' in (a) is an information which has already been owned in common, or already known, with the utterer and the hearer so it can be regarded as a presupposition of the utterance. And the ketâbi 'a book' in (b), on the other hand, is a newly introduced information by the speaker in the discourse, hence the hearer will never be able to predict that the other party shall refer to 'a book' beforehand. Consequently, one of the ways to express old/new information in Persian is concerned with its word order. The old information tends to be placed at the head of a sentence, whereas the new information placed at the final position. As is seen in the translation of examples, old information in English can be expressed with the definite article 'the', while new information with the indefinite article ' $a / a n$ '.

(5) There are several researchers who have worked on the Persian verbs in terms of case grammar. Palmer (1971) tries to explain the ezafe construction by the framework of transformational approach with some reference to case grammar. Sheik (1978) has provided a semantic classification of Persian verbs, although he has included only compound verbs in his classification, which only takes account of only the entities that co-occur with verbs in surface structures.

Aghbar (1981) has also provided a semantic classification of Persian verbs based on the case grammar fairly extensively, as he claimed that the purpose of his study is to provide a semantic classification, not an exhaustive inventory of the verbs for each type. He classified Persian verbs into four semantic types: basic, experiential, benefactive and locative verbs. It seems that his classification was satisfactory as far as its case frame verification is concerned.

The 'cases' which these analytical procedures rely on, do not solely mean the declentional or inflectional cases, but the cases with substantial universality as well. Following are the major cases which have been basically treated in the traditional case theory. 
a) Agentive: a case which typically refers to an animate object, considered to cause an action indicated by a verb. (abbreviated as $\mathrm{Ag}$ )

b) Instrumental: a case which typically refers to an inanimate object or a force which is a cause of an action or state indicated by a verb. (abbreviated as I)

c) Affected: a case which typically refers to an inanimate object which is affected by an action or state indicated by a verb. (abbreviated as Af)

d) Effected: a case which typically refers to an object which is brought about as a result of an action or state indicated by a verb. (abbreviated as Ef)

mahmud manzel-râ sâxt.

Mahmud house-obj. built

'Mahmud built the house.'

e) Locative: a case which typically refers to those which indicate a spatial position or direction of an action or state indicated by a verb. (abbreviated as L)

'u 'az 'ânjâ gozašt.
he from there passed
'He passed there.'

f) Recipient: a case which typically refers to an animate object which is affected an action or state indicated by a verb. (abbreviated as $\mathbf{R}$ )

i) verbs which signify possession as dâštan 'to have'

ii) perceptual verbs as didan 'to see'

iii) verbs which signify mental state as fekr kardan 'to think'

diruz. man mo'allem-râ didam.

yesterday I teacher-obj. saw

'I saw the teacher yesterday.'

In Persian it is noticeable that there is a high correlation between word order and syntactic relation; in the unmarked case, the 'subject, object, verb' word order shall normally be acceptable. Note that further analysis of the semantic relations between each sentence element in a sentence proves that the grammatical subject or object do not always carry certain fixed semantic functions with them. In fact, sentence patterns in case grammar or Valenz theory shall be indicated differently from those in traditional ones. For example, in Valenz theory, the verb 'to give' which governs three features as a subject, a direct object and an indirect object will be indicated as 'trivalent' which means to take three 'arguments' as its essential 'actant'. This theory originates in the study of basic verbs in German and was presented as a form of dictionary Wörterbuch zur Valenz, und Distribution deutscher Verben $(1969,71)$ by G.Helbig and W.Schenkel. Cf. the preface of Konishi (1980). And for the general discussion of the valency, see Lyons (1977) pp.481-8.

Thus, the 'case' in the case theory may correspond to a series of certain human recognition model to the event around him/her; who has caused, to whom it has occurred, what has changed, etc. Let us now illustrate briefly the concept of the case.
(a) hasan dasthâyeš-râ bâ 'âtě̌ garm kard.
Hasan his hands-obj. with fire warmed up
'Hasan warmed up his hands with fire.'
(b) 'âteš dasthâyeš-râ garm kard.
fire his hands-obj. warmed up
'Fire warmed up his hands.'
(c) dasthâyeš garm šod.
'His hands warmed up.'
his hands warmed up 
The noun phrases hasan in (a), 'âteš in (b) and dasthâyeš in (c) are all regarded as 'subject' in terms of grammatical function, although each has different semantic functions respectively. The subject hasan in (a) is an animate entity which causes an action of 'warming up' his hands, so it should be considered as the agentive case. And the subject 'âteš in (b) is an inanimate mean or a cause of an action/state, thus considered as instrument case, while the subject dasthâyeš in (c) is a thing which is affected, an action caused by an agent and instrument, so considered as affected case.

Various other case features have been proposed by scholars, although they mostly seem to be synonymous and need not to be employed thoroughly.

(6) Blake (1994) claims that 'there is also a lot of confusing variation in the terminology. Fillmore began by positing a universal set of relations with traditional case-like labels (agentive, instrumental, dative, factitive, locative, objective) (1968: 24-5), but later switched to agent, experiencer, instrument, object, source, goal, place and time, which, except for object, are more semantically transparent and less confusable with traditional case labels (1971). He called these 'syntactic-semantic relations' cases and his conception of grammar and its congeners came to be referred to as case grammar (1968: 19). It has become common over the last generation to refer to Fillmorean-type cases as deep cases and traditional cases as surface cases'. For more detail in differing opinions among the scholars for other cases, see Dilon (1977) Chapter 5: Semantic Roles.

( 7 ) A similar example occurs in English verb; 'This place commands a fine view.'

( 8 ) Hence the possession construction of (19) and (20) can not be paraphrased with budan, while (21) and (22), can as follows. And the adjective pattern dârâ-ye...budan can take place both in the possessive and locative construction.

(a) ?yek ketâb piš-e man 'ast. 'I am in possession of a book.'

(b) ?yek gorbe piš-e doxtar-e man 'ast. 'My daughter is in possession of a cat.'

(c) dar žâpon kuhhâ-ye boland ziyâd 'ast. 'There are many high mountains in Japan.'

(d) dar 'in bâq deraxtân-e sib ziyâd 'ast. 'There are many apple trees in this garden.'

(e) man dârâ-ye yek ketâb hastam. 'I have a book.'

(f) žâpon dârâ-ye kuhhâ-ye boland-e ziyâdi 'ast. 'Japan has many high mountains.'

Neither (a) nor (b) carry the implication of ownership of 'a book' or 'a cat'. The book or the cat, in this construction, may belong to somebody else, but may be kept by the subject man or doxtar-e man for a short time. When using dârâ-ye...budan, a quantifier should be carried with a noun phrase. And this form is more formal way of saying, thus normally used in writing. And the following examples ( $g$ ) through (j) seem to present us with problematic cases which do not apply to the above conditions.

(g) *'in miz do ketâb dârad. 'This table has two books on it.'

(h) *'in miz dârâ-ye do ketâb 'ast. 'This table has two books on it.'

(i) ruye 'in miz do ketâb 'ast. 'There are two books on this table.'

(j) 'in miz do pâye dârad. 'This table has two legs.'

Although we need to consider further for the relationship between the existential and possession construction, it can not be discussed here for lack of space.

(9) This point needs further consideration, since the sentences (23) and (24) are not completely synonymous each other; (23) seems to carry connotations of permanent or fixed existence of 'windows' in the room, while (24) can rather carry temporary one as such in the case that those windows are fitted temporarily in the room which is, for example, under construction.

(10) See Blake (1994:74-75).

(11) For example, Dixon (1991) and Yoshikawa (1995) advanced a case theory and proposed a new approach to English grammar, investigating the behavior of verbs and new 
classifications on semantic principles.

\section{References}

Aghbar, Ali Asghar. Case Grammar and Persian Verbs, PhD thesis. Georgetown University, 1981.

Amin-Madani,Sadegh, and Dorothea Luts. Persische Grammatik. Julius Groos Verlag, 1972.

Blake, Barry J. Case. Cambridge University Press, 1994.

Dilon, G.L. Introduction to Contemporary Linguistic Semantics. Prentice-Hall, 1977.

Dixon, R.M.W. A New Approach to English Grammar on Semantic Principles. Oxford University Press, 1991.

Fillmore, Charles J. 'The Case for Case,' in Universals in Linguistic Theory, ed. Emmon Bach and Robert T. Harms. Holt, Rinehart, and Winston, 1968.

Fillmore, Charles J. 'Toward a Modern Theory of Case,' in Modern Studies in English, ed. David Reibel and Sanford Schane. Prentice-Hall, 1969.

Fillmore, Charles J. 'Some problems for case grammar,' in Working Papers in Linguistics, Ohio State University 10, 1971.

Fillmore C.J. Kakubunpô no genri. Sanseido, 1975.

Konishi, Tomoshichi. A Dictionary of English Word Grammar on Verbs. Kenkyusha, 1980.

Lyons, John. An Introduction to Theoretical Linguistics. Cambridge University Press, 1968.

Lyons, John. Semantics 1. Oxford University Press, 1977.

Lyons, John. Semantics 2. Oxford University Press, 1977.

Nawata, Tetsuo. Nawata's One-Volume Persian-Japanese Dictionary. Matsue: Hôkôsha Press, 1981.

Palmer, Adrian S. The Ezafe Construction in Modern Standard Persian, $\mathrm{PhD}$ thesis. University of Michigan. 1971.

Sheik, Habib. The Semantic Structure of Compound verbs in Modern Persian and their English Equivalents: a Comparative Study. Ph.D dissertation. University of Nebraska, 1987.

Windfuhr, G.L. Persian Grammar - History and State of its Study. Mouton, 1979.

Yokoyama, Shozo. 'A Syntactic Study on the Verb Pattern in Modern Persian', Annals of Japan Association for Middle East Studies. Japan Association for Middle East Studies, 1994.

Yokoyama, Shozo. 'On Persain Adjectives', The Korean Journal of the Middle East Studies. Korean Association for Middle East Studies, 1992.

Yoshikawa, Chizuko. Nichiei hikaku dôshi no bunpô. Kuroshio Press, 1995. 